Article

\title{
Resources and Rules of the Game: Participation of Civil Society in REDD+ and FLEGT-VPA Processes in Lao PDR
}

\author{
Irmeli Mustalahti ${ }^{1}{ }^{*}$, Mathias Cramm ${ }^{1}$, Sabaheta Ramcilovic-Suominen ${ }^{1}$ and \\ Yitagesu T. Tegegne ${ }^{2}$ \\ 1 Department of Geographical and Historical Studies, University of Eastern Finland, Yliopistokatu 7, \\ 80100 Joensuu, Finland; m.cramm@gmail.com (M.C.); sabaheta.ramcilovik-suominen@uef.fi (S.R.-S.) \\ 2 European Forest Institute, Yliopistokatu 6, 80100 Joensuu, Finland; yitagesu.tekle@efi.int \\ * Correspondence: irmeli.mustalahti@uef.fi; Tel.: +358-505-632-071 \\ Academic Editors: Esteve Corbera and Heike Schroeder \\ Received: 31 October 2016; Accepted: 14 February 2017; Published: 21 February 2017
}

\begin{abstract}
Reducing Emissions from Deforestation and Forest Degradation (REDD+) aims to achieve its purpose by working across multiple sectors and involving multilevel actors in reducing deforestation and forest degradation in tropical countries. By contrast, the European Union (EU) Action Plan on Forest Law Enforcement, Governance and Trade (FLEGT) and its Voluntary Partnership Agreements (VPAs) focus on forestry and functions at a bilateral state level. The FLEGT Action Plan specifically aims to tackle illegal logging and improve forest governance in countries exporting tropical timber to the EU. Since illegal logging is just one driver of forest degradation, and legalisation of logging does not necessarily reduce deforestation and forest degradation, the two instruments differ in scope. However, by addressing the causes of forest degradation and their underlying governance issues, the FLEGT VPAs and REDD+ share many functional linkages at higher levels of forest policy and forest governance. The contribution and participation of civil society organisations (CSOs) and other actors are imperative to both processes. Our study is based on a survey of key actors (national and international) in REDD+ and FLEGT VPA processes in the Lao People's Democratic Republic (Lao PDR). Our analysis was guided by the theoretical perspectives of the policy arrangement approach and examination of two specific dimensions of this approach, namely resources and rules of the game. This paper argues that participation of CSOs in both processes is crucial because it facilitates and nurtures much needed cooperation between other national and international actors. The paper concludes that participation of CSOs could bring valuable information and knowledge into REDD+ and FLEGT VPA processes, thus contributing to increased legitimacy, justice and transparency.
\end{abstract}

Keywords: REDD+; FLEGT VPA; civil society organisations; participation; resources; rules of the game; policy arrangement approach; Lao PDR

\section{Introduction}

Climate change induced by human activities is well substantiated, for instance as demonstrated by the Intergovernmental Panel on Climate Change in the Fifth Assessment Report [1]. Deforestation and forest degradation are a major concern globally because they are one of the drivers of global warming. As much as $10 \%$ of the annual anthropogenic greenhouse gas emissions is estimated to be due to tropical deforestation and forest degradation [2]. Indeed, tropical forests showed a significant trend of increased annual forest loss between 2000 and 2012 [3]. Therefore, sustainable 
forest management (SFM) and conservation can play a key role in reducing global anthropogenic greenhouse gas emissions [4,5].

Scholars argue that countries in the tropics often have institutional, economic and political disadvantages in responding effectively to multifaceted and complex challenges, such as those related to society-nature interactions [6-9]. The international community has therefore taken a substantial interest in facilitating the national efforts of tropical countries to reduce deforestation and forest degradation because such interventions are of interest and benefit at a global scale. Different approaches have arisen in the wake of this interest. Two such approaches are (i) Reducing Emissions from Deforestation and Forest Degradation in Developing Countries, and the role of conservation, sustainable management of forests and enhancement of forest carbon stocks in developing countries (REDD+) and (ii) the European Union's Forest Law Enforcement, Governance and Trade (FLEGT) Action Plan and Voluntary Partnership Agreements (VPAs). REDD+ is being negotiated under the United Nations Framework Convention on Climate Change (UNFCCC), and developing countries are being supported by several donor countries, especially Norway, as well as international organisations such as the UN and the World Bank. The scope of REDD+ is to address the direct and underlying drivers of deforestation and forest degradation, and under this approach, countries are paid based on their performance in forest carbon sequestration. The latest climate agreement negotiated in Paris features an explicit stand-alone article [10] (Article 5) devoted to REDD+ that sends a clear message that REDD+ and forests will play a role in the fight against climate change. Meanwhile, the EU FLEGT Action Plan was developed in 2003 in response to imports of illegally sourced timber and vast illegal logging operations in supplying timber products [11]. The overall aim of the FLEGT VPA is to limit the import of illegal timber into the EU and reduce illegal logging, while strengthening land tenure, access and rights, and increasing the participation of different actors [11]. This should help lead the way to SFM (sustainable forest management), a principle that is adopted by most countries through the Rio Conventions [12]. FLEGT VPAs are negotiated at a bilateral level between the European Commission (EC) representing the EU member states and an individual partner country [13].

REDD+ works across multiple sectors and thus involves many different actors. Incorporating the views of all of these actors in REDD+ planning and implementation processes is important to ensure that REDD+ processes and finance will be accessible and fair for the different actors [14-16]. The FLEGT VPA process is negotiated and implemented as an agreement between the EC and each specific country individually. The VPA agreements focus solely on forestry and illegal logging, and also affect numerous actors at the national scale that are either directly or indirectly in touch with forests and involved in forestry related matters $[17,18]$. By addressing the causes of forest degradation and their underlying governance issues, negotiation and implementation of the FLEGT VPAs share many functional linkages with REDD+ processes $[19,20]$. It is argued that REDD+ should include safeguards that recognise and protect the continuity of multipurpose functions of the forest for local people and avoid dependence on external payments $[15,21,22]$. In a similar fashion, VPAs in principle have to include provisions for justice and sustainability matters [13]. In this context, the participation of CSOs is essential in terms of developing such safeguards for REDD+ and FLEGT.

The aim of this paper is to understand how and to what extent CSOs are engaged in REDD+ and in the emerging FLEGT VPA process in the Lao People's Democratic Republic (PDR). In addition, the paper aims to clarify the possible role which CSO participation plays in facilitating the implementation of the two processes. REDD+ in Lao PDR is at the stage of developing the national REDD+ strategy, while the VPA process is at the pre-negotiation phase. In this paper, we aim to explore these two processes through three research questions: (i) how are CSOs currently participating in REDD+ and VPA processes? (existing participation); (ii) how can the role of CSOs be strengthened? (potential participation); (iii) how can CSOs foster cooperation between the REDD+ and VPA processes?

In addressing these questions, the paper contributes to the literature on the role of non-state actors in environmental and forest governance processes and interventions in general terms as well as to the emerging literature on the same issue in the context of FLEGT and REDD+. While the literature on 
the non-state actors' role and participation is rather well developed in both general terms and with regard to FLEGT and REDD+ processes, such analysis in the case of Lao PDR is a novelty and is much needed. Considering the country's single party system, the involvement and role of non-state actors, such as CSOs, is an issue that has lagged behind, both in practice and in academic work. A limitation of this study is that we had difficulty in accessing information and objective opinion on the issues in focus, which in particular reflected the recent emergence of domestic CSOs and that their operations and involvement is highly regulated in Lao PDR. This situation is also clearly seen in the study sample which was dominated by international NGOs due to the difficulty of identifying domestic CSOs working on FLEGT and REDD+ in Lao PDR.

We use the policy arrangement approach (PAA) proposed by Bas Arts and colleagues to analyse the involvement of CSOs in FLEGT and REDD+ processes and their role in facilitating implementation of and interactions between the processes in Lao PDR. One of the key reasons for adopting this framework for our study is the concept of "political modernisation", which is the "building block" on which the PAA rests. The concept of political modernisation, as further explained in the section describing the theoretical framework, is about the change in forest governance represented by the emergence of new actors. Therefore, we felt that the PAA was particularly suited even though there are various other frameworks for facilitating analyses of environmental governance. We also opted for the PAA framework due to its strong emphasis on power and power relations-a dimension which is largely overlooked in the analytical frameworks emerging from the schools of institutionalism and institutional economics. Our conceptual understanding of PAA and its relevance are further explained in Section 3 which introduces the theoretical framework of the study. The last part of the article is organised in the following sections: Section 4 presents research methods; Section 5 presents and discusses the results; and Section 6 draws some conclusions and offers recommendations. However, first, in Section 2 we discuss the case study (REDD+ and FLEGT-VPA processes) in Lao PDR.

\section{Case Study in Lao PDR: Forestry Governance, CSOs, REDD+ and FLEGT VPA}

\subsection{Forest Governance and Participatory Forestry in Lao PDR}

Lao PDR is a tropical country in Southeast Asia that shares most of its border with Vietnam and Thailand. Forest cover in the country is high and is estimated at around $40 \%$, but deforestation levels have been alarming. Lao PDR has vast natural resources that attract foreign direct investment with the aim of developing commercial agriculture and forestry production [23]. At the same time, the government of Lao PDR and donor countries have agreed to pursue forest conservation through global mechanisms such as REDD+ and FLEGT. Consequently, the various types of investments and conservation practices for managing natural resources and land are creating more pressure on rural communities but also opportunities to which these communities must adapt in order to secure their livelihoods [24,25].

Although Lao PDR is well-endowed with natural resources that can make a major contribution to the country's long-term economic development, the country has experienced an alarming deforestation rate in the last two decades. From 1982, the forest area has been decreasing dramatically, at an estimated annual average net deforestation rate of $0.7 \%$, or forest loss of about 76,000 ha per annum [26]. The immediate and underlying factors causing deforestation and forest degradation in Lao PDR are well covered in [26,27]. Lao PDR state sources name the following activities as the principal causes of deforestation: shifting cultivation, commercial agriculture, forest fires, and mining operations in forested areas. Extraction of wood (legal and illegal) and unsustainable non-timber forest product harvesting are named as the major causes of forest degradation. Factors underlying these causes include population growth and infrastructure expansion, urbanisation, construction of roads, hydropower plants and increasing price and demand for raw materials (e.g., minerals, timber) in the regional and global markets. However, scholars increasingly question these factors and sources, and point to state-supported large-scale land concessions for fast-growing plantations and development projects as 
the main reasons for declining forest cover in Lao PDR, rather than shifting cultivation practiced by upland minorities [28-30].

In Lao PDR, villagers have been involved in so-called participatory forestry since the 1990's [31,32]. The first participatory forest management (PFM) intervention was the Joint Forest Management approach introduced by the Lao Swedish Forestry Programme [33]. In the 1990's, the long-term rights for use of natural forest could be allocated to individuals and organisations [34] (art.5, pp. 48-54). The law made it possible to develop another participatory forestry model with a deeper involvement of villagers, the Forest Management and Conservation Programme (FOMACOP). FOMACOP, supported by World Bank and Finnish development cooperation, operated as a pilot project of participatory sustainable production forestry. This project paid special attention to the building of villager organisations and entrepreneurial development as well as to the technical aspects associated with forest management carried out by villagers [35].

The concept of practising participatory forestry in production forests through village organisations lost political support in Lao PDR and FOMACOP ended in 2001 [36]. The Forest Sector Strategy [37] instead adopted a timber production approach under sustainable forest management (SFM) in cooperation with local villages. The stated goal was decentralisation of land and forest resources. However, from a critical point of view, rather than decentralising natural resources and providing greater rights and control to local villages, the initiative at the time also led to re-centralisation of power [38]. In more recent years, there has been renewed interest in and political acceptance of village forestry, which is, however, highly regulated. In this vein, the former FOMACOP was replaced by the Sustainable Forestry for Rural Development Scaling Up (SUFORD-SU) Project (another project supported by the Finnish development aid) that follows more closely the political decisions and regulations of Lao PDR. Production forest areas under SUFORD-SU are no longer allocated to a particular village locality. Instead, management of production forest areas must be implemented jointly by several villages, their village forest organisations and district forest management units [39-41].

Currently, the involvement and roles of villagers in SFM are embedded in the existing laws and regulations and in the National Growth and Poverty Eradication Strategy of Government of Lao PDR [42]. The most relevant laws dealing with CSO participation include: (i) the Forest Law [34]; (ii) Prime Minister's (PM) Decree No. 59 [43]; (iii) Regulation No. 0204 from the Ministry of Agriculture and Forestry (2003) and (iv) the Forestry Strategy [37]. These laws have apparently strengthened the involvement of CSOs in community-based forestry interventions in Lao PDR, and provide more freedom to develop village forestry models based on decentralised natural resources rights and control by local villages. In summary, the last two decades have seen a shift towards decentralisation, a shift back to recentralisation, and now recently again a shift towards decentralisation of natural resources in the Lao PDR.

\subsection{Civil Society Organisations (CSOs) in Lao PDR}

In 2009, the Government of Lao PDR [44] passed decree No. 115/PM which introduced national CSOs in the country, or non-profit associations (NPAs) as they are called. According to the decree, NPAs should contribute to socio-economic development and poverty eradication. In this paper, "CSOs" refers to Lao NGOs/NPAs, community-based organisations and mass organisations as well as international NGOs, which may have a role to play in the REDD+/VPA processes in the country. However, it should be pointed out that the Lao-based organisations are highly regulated by the state and their freedom of action and expression is still tightly monitored. In fact, the so-called "mass organisations" are one of the four key institutions where leading figures are party members [45]. During this study, we found that the national CSOs were not yet actively involved in the REDD+/FLEGT processes. Therefore, the data and results presented in this study are dominated by information from international NGOs.

In the context of Lao PDR's single-party and authoritarian ruling system, it is interpreted as quasi normal that the NPAs would be under governmental control and in line with government policies and goals [46,47]. For instance, the decree on NPAs stipulates that "undermining the national, collective 
and individual interest is forbidden" for NPAs [44]. Another decree [48] further constrains the activities of NPAs by imposing stricter rules for obtaining finance and by limiting the fields in which they may work. Besides this "new civil society" initiative, Lao PDR has four so-called mass organisations (including the Farmers' Union and Women's Union) that have close ties to the Party. These mass organisations have extensive organisational networks stretching from the top of the party hierarchy down to the village level in order to disseminate information and scale up activities $[47,49]$. In the case of new development activities, international NGOs, on the other hand, are comparatively more active in Lao PDR, and have recently been recognised by the government as "important contributors to national socio-economic advancements" [50]. However, their functional freedom also hangs in the balance, because the new draft decree places them under more stringent supervision by the Ministry of Foreign Affairs [51]. With the constant change in political position from centralised to decentralised, market to state regulated and an ad-hoc manner of institutional and regulation building, it remains to be seen what role CSOs will play in the country's development and in the processes of FLEGT and REDD+. However, there are hopes that the situation might change for the better with the appointment of the new prime minister in January, 2016, who apparently has adopted a more "open approach" to development and natural resource governance.

\subsection{National REDD+ and FLEGT VPA Processes and Organisational Structures}

The key challenges in forest and land governance in Lao PDR have been well addressed by several scholars (see for example references [26-32]) who all discuss two key challenges: the ambiguous and uncertain laws and regulations in land-use planning and allocations that further create opportunities for unsound resource use practices, and poor law enforcement performance. To address the challenges facing forest resources in the country, Lao PDR is participating in REDD+ and FLEGT VPA processes. Lao PDR was one of the first 14 countries to become a REDD+ country participant under the Forest Carbon Partnership Facility (FCPF) of the World Bank in 2008. The country's Readiness Preparation Proposal (R-PP), which is the most central national-level document that defines how a country actually wants to implement REDD+, stems from 2010. Official communications from Lao PDR requesting entry into VPA negotiations date from April 2012. By entering into a VPA with the European Commission (EC), Lao PDR, at least in theory, aims to address the problem of illegal logging activities, improve governance in the forest sector, guarantee access of timber products to the EU markets, build capacities, and increase revenue from timber exports.

\subsubsection{REDD+ Process in Lao PDR}

Since 2007, Lao PDR has been involved in international negotiations through a REDD+ mechanism, and the government has voiced support for an internationally binding agreement. REDD+ preparations are being supported by FCPF, the Forest Investment Programme, and UN-REDD. The Lao PDR R-PP was submitted in December 2010 and accepted in 2011 [26]. Currently, the country is gaining experience from different REDD+ pilot projects and other readiness activities and setting up REDD+ institutions. In 2011-2012, the country started an institutional reform which reorganised the responsibilities of government bodies in relation to REDD+. A new Ministry of Natural Resources and Environment (MoNRE) was established which also led to changes in the structure of the existing Ministry of Agriculture and Forestry (MAF). Prior to the establishment of MoNRE, all forestry and therefore REDD+ and FLEGT related matters fell under the MAF or, more precisely, under its Department of Forestry (DoF). Once MoNRE was established in 2012, the government merged the former Division of Forest Conservation and the Division of Forest Protection and Restoration at MAF's Department of Forestry (DoF) into the Department of Forest Resource Management (DFRM) at MoNRE [52]; the Division of Forest Production remained under the DoF at MAF.

The REDD+ Division was placed under the DFRM at MoNRE, while the REDD+ Office was under DoF at MAF. These unclear mandates between the ministries caused a lot of ambiguity and overlap in REDD+ institutional settings, and the projects related to REDD+ and production and those related to 
conservation and protection are managed by two different ministries (MAF and MoNRE, respectively). These overlapping roles have caused conflicts, but more importantly they have provided opportunities for the private sector to establish land investments and timber extraction under a grey area of legality and with little or no participation of local communities [49,53-55]. Furthermore, REDD+ activities were transferred back to MoNRE [56]. However, in late April 2016, the new government of Lao PDR decided to restructure some ministries and to reconsolidate the forest sector under one ministry-the Ministry of Agriculture and Forestry. The Minister of MoNRE officially transferred the DFRM to the Minister of MAF on 19 August 2016. According to the official "Handing over Note", the DFRM under the MoNRE was returned to MAF. The two national REDD+ offices will be merged into one office under DoF.

The R-PP defines an institutional setup for national and subnational levels for governing REDD+ in Lao PDR [57]. In accordance with this setup, a National REDD+ Task Force was established in 2008 under the leadership of the Director-General of Forestry, and composed at that time of 12 members from various organisations and an array of legal mandates [56]. Following the establishment of MoNRE and under the ongoing institutional reforms during 2012 and 2013, the Task Force was moved from MAF to MoNRE, and was expanded to include first 24 members, from 18 ministries and various cross-sectoral organisations [58,59], and then later 30 members. Initially, the Director-General of DFRM chaired the Task Force, then the Vice-Minister of MONRE took over the chairmanship. Now that forest management is again solely the responsibility of MAF, the leadership of the National REDD+ Task Force has returned again to MAF. Now MAF is considering who will lead the Task Force, and how to convene and make decisions. The National REDD+ Office acts as a secretariat to the National REDD+ Task Force. Similarly, provincial REDD+ Task Forces (PRTFs) are supported by Provincial REDD+ Offices (PROs). To date, PRTFs and PROs have been established in three provinces-Houaphan, Luang Prabang, and Champasack. Four provinces-Xayaboury, Luang Namtha, Bokeo, and Oudomxay-are also to establish PRTFs and PROs before the end of the 2016.

\subsubsection{FLEGT-VPA Process in Lao PDR}

Voluntary Partnership Agreements (VPAs) are a key instrument of the EU FLEGT Action Plan. The VPA is a voluntary bilateral trade agreement between the EU and the government of a timber producing and trading partner country. The VPA becomes legally binding upon signature and ratification by both parties [11]. In Lao PDR, MAF-specifically its Department of Forest Inspection (DoFI) - is the ministry with lead responsibility for negotiating the VPA. The FLEGT VPA informal negotiation started in April 2012, although it was not until June 2015 that the Government Office of Laos approved the start of negotiations. A FLEGT Standing Office was opened by the MAF in October 2013 [60]. In July 2014, a workshop on actor engagement involving participants from the government, private sector, CSOs and academic institutions was held in Lao PDR. At the conclusion of the workshop, participants identified the following as the most essential issues to be resolved in order to advance the VPA process: (1) establishing a national steering committee for the VPA process; (2) building the capacity of actors; (3) strengthening communication on FLEGT among actor groups [61]. During 2014, a number of workshops and events organised by the EU and German agency for international cooperation (GIZ) were held to promote EU FLEGT in Lao PDR and in Southeast Asia in general. The options for inclusive participation, building and involvement of civil society in the process and legal enforcement were reviewed and discussed. The conclusion was that more work and a willingness to foster an open and transparent approach was needed for the FLEGT VPA to be successfully implemented in Lao PDR. These options were revisited almost three years later in December 2016 when a draft Work Plan for Forest Law Enforcement and Governance (FLEG) in ASEAN (Association of South East Asian Nations) was developed.

At the present time, Lao PDR is finalising its legality definition and-as the head of the Lao FLEGT Standing Office stated at the ASEAN meeting in December 2016-the aim is to conclude the VPA negotiations with the EU in 2018. The FLEGT VPA meetings are still ongoing and according 
to EUFLEGT news (accessed on 25 January 2017), the recent meeting on FLEGT VPA in Lao PDR acknowledged that engagement of private sector and civil society is the main challenge.

Concerning activities on the ground, significant support from the EU is currently organised under the auspices of the GIZ and its ProFLEGT project which aims to conclude a VPA between the EU and the government of Lao PDR. The project activities have so far focussed on support and capacity building for governmental agencies, as well as policy coordination. However, activities on the ground related to testing and implementation of the system in the three pilot provinces-including Sayaboury, Khammouane and Attapeu—have not taken place as originally planned. In addition to the Pro-FLEGT project, the EU-FAO FLEGT Programme was established in 2012. This Programme aims to improve awareness and strengthen the participation of CSOs and forest communities in the FLEGT VPA countries, and has since been active in the Lao FLEGT policy process.

For the government of Lao PDR, a VPA with the EU could provide an opportunity to resolve some of these issues and privileged access to the European market. Nevertheless, a lot will depend on whether FLEGT VPA will catalyse fundamental governance and institutional reforms, and on whether such reforms will address illegal logging and deforestation outside of the forestry sector, such as that which originates from agricultural and other development sectors. However, such a major shift away from the current governance norms is not likely to happen in the near future. This argument is based for example [62]. The main VPA impacts in the country are therefore expected to be in terms of strengthening forest governance generally.

\section{Theoretical and Analytical Framework: Political Modernisation and the Policy Arrangement Approach (PAA)}

Our analysis for exploring the participation of CSOs in REDD+ and FLEGT VPA processes in Lao PDR is guided by the policy arrangement approach (PAA). The PAA is defined as "the temporary stabilisation of the content and organisation of a policy domain" [63] (p. 96). It is helpful to examine some of the theoretical and conceptual underpinnings behind the PAA framework in order to better understand the REDD+ and FLEGT-VPA processes and the roles of CSOs. The concept of political modernisation, which is defined as "a comprehensive process of changes in the political domain of society" [63] (p. 101), may serve as a useful starting point. According to this concept, political modernisation refers to the process of shifting and redefining the relationships between the state, the market and civil society. These processes are characterised by the relative increase of political power of non-state actors, such as CSOs and private-sector actors [63-65].

Political modernisation consists of two distinct phases: early modernity and late modernity. Early modernity relates to the politics revolving around a strong nation-state model and the belief in a highly manageable society and nature [65] (p. 343). Early modernity is characterised by a regulatory state that is dominant over the market and civil society and optimism over such a state's capability to solve societal problems by rational policy making and comprehensive planning [65] (p. 343), [66] (p. 29). Late modernity is characterised by a discourse of governance, interdependence and the inevitability of the need for cooperation between government, market and society where there can be "no monopoly of knowledge, problem-solving, or steering capacity", as explained in [63] (pp. 101-102).

One way in which late modernity manifests itself is through what is understood as multilevel governance, or multiactor governance. Multilevel implies that governance takes place on multiple levels from local to global, and that these levels are not 'separated' from each other; rather, their boundaries are blurred and they are in constant interaction with each other. Multiactor refers to the number of different actors besides the state that can be found at the different levels and which constitute what is understood as governance $[67,68]$. Some examples of these actors in forest governance include the private sector, civil society, international actors, local communities and forest users.

The PAA framework comprises four interrelated analytical dimensions: (i) actors and their coalitions; (ii) resources and power; (iii) discourses; and (iv) rules of the game [64]. Bas Arts and colleagues state in their publications on the PAA that all four dimensions should be considered together 
in the analysis and that change in one of them means a change in one or more of the other three dimensions. While all these dimensions link to our key research question related to participation, we decided, however, to focus on two dimensions of PAA because those were the most crucial issues based on our pre-study analysis: rules of the game and resources, which refer to actors' capacities-economic, political, cultural, knowledge and beyond-and the extent to which actors are able to exert influence over other actors (i.e., actors' power relationships). The rules of the game can be understood by the following essential questions [63,65]: Who decides the agenda? Who makes the decisions? Due to the interrelatedness of the dimensions of a policy arrangement, these issues of "rules of the game" are closely related to actors' resources and thus also to power [69]. By contrast, resources are defined as assets that policy actors have or can mobilise to achieve their policy goals. The division of power and influence between these actors determines the degree to which actors can influence the policy outcomes. While different types of power capacities are certainly interwoven with each other and they can all be relevant, two of these power types may be of special interest in the context of this study: the political and the knowledge-based power capacities that are a central part of the rules of the game in any governance process.

For participation and further cooperation to be realised, actors can be presupposed to have and hold power, because power is required for actions such as formulating new rules, influencing decisions or reframing discourses that contribute to making participation/cooperation happen. Further, the achieved outcomes depend on the types of resources actors possess and how they use them, and on how actors play the "policy game" and are affected by the rules. Rules of the game decide the (non) existence of participation-i.e., who may participate and who decides this; the actors with the "strongest" resources (e.g., political and knowledge-based power) are the ones who make the decisions and achieve outcomes. The results of this study (Section 5) are presented in two sections based on our interview findings on the CSOs' resources and role in the 'rules of the game': (1) Resources of CSOs and challenges to CSO participation in REDD+ and FLEGT VPA processes; and (2) Rules of the game from the perspectives of CSOs facing challenges in fostering cooperation in REDD+ and FLEGT-VPA processes. Prior to the results and discussion, the research materials and methods are presented.

\section{Materials and Methods}

The first step to collect the data for this study in 2014 was an extensive review of existing scientific and grey literature, including policy documents, briefing notes and policy updates. The literature review provided important contextual information that was then used for creating an online questionnaire-based survey. This enabled the collection of more specific and relevant data for the study.

The second step in 2014 was identification of key national and international policy actors (representatives of international and national organisations, bilateral and multilateral donor agencies and national level ministries and relevant departments) leading and representing their respective organisations in the REDD+ and FLEGT related processes. In total, 51 contacts were identified and contacted (named in Table 1 as pre-survey interviews) with the help of international and national CSOs and bilateral project staff active in Laos. However, only 39 could be considered to have relevant information related to more recent development in REDD+ and FLEGT processes.

In the third step in August 2014, the identified 39 key respondents were invited to take part in an online survey. These organisations and actors were first contacted by email and then were either interviewed personally by phone or in face-to-face interviews in Lao PDR. Following the interviews, eventually 17 out of 39 respondents (response rate of $44 \%$ ) took a part in the on-line survey.

In the fourth and final step, key-informant interviews were carried out with selected actors to triangulate the data and generate understanding of the historical context of forest governance in Lao PDR. Three of these informants participated in the survey, but the seven additional informants did not. The face-to-face interviews took place in Vientiane in January and April 2015. In 2016, five of informants were re-contacted by email in order to up-date the information. The distribution of organisational actors in different data collection phases is presented in Table 1. 
Table 1. Distribution of organisational actors in the survey and interviews.

\begin{tabular}{cccc}
\hline Organisational Type & $\begin{array}{c}n \text { (pre-Survey } \\
\text { Interviews 2014) }\end{array}$ & $n$ (Survey 2014) & $\begin{array}{c}n \text { (Key Informant } \\
\text { Interviews 2015) }\end{array}$ \\
\hline Government & 3 & 2 & \\
National NGO & 1 & 2 & 1 \\
Community-based organisation & & 2 & 2 \\
International NGO & 4 & 5 & 2 \\
Intergovernmental organisation & 5 & 1 & 4 \\
Foreign government agency & & 1 & 1 \\
Private sector & & 1 & 10 \\
Academia & 13 & 17 & \\
Total & 13 & & \\
\hline
\end{tabular}

In the analysis of the survey data, distinct approaches were employed for answers to fixed-choice questions and open-ended questions. Responses to fixed-choice questions were graphically displayed in an easily understandable format as quantitative data using Microsoft Excel, and these graphs were then transferred to Microsoft Word. For open-ended questions, analysis was conducted in Microsoft Word where responses by individual respondents were examined to identify main themes or topics in their responses. The data from the interviews conducted in Lao PDR were used to support and complement the survey data so as to provide a deeper understanding and a more refined overall context of the topic.

\section{Results and Discussion}

\subsection{Resources of CSOs and Challenges to CSO Participation in REDD+ and FLEGT VPA Processes}

This section addresses the dimension of resources of PAA, interpreted and used hereafter as the capacities of CSOs (as one policy actor) to exert influence over other actors (i.e., actors' power relationships). Figure 1 summarises the types of roles that the CSOs have in the REDD+ process in Lao PDR according to respondents. It is interesting to note that none of the respondents thought that the CSOs-although participating - were actually affecting any decisions surrounding the REDD+ process. Rather, CSOs were seen to have other kinds of roles. Most of the respondents (13 out of 17) acknowledged that the CSOs' role has been to raise awareness and engage in building capacities. For instance, a respondent from a national CSO commented that CSOs had been raising awareness on both REDD+ and FLEGT VPA processes among CSO members. Figure 1 also indicates that the CSOs had a role in terms of implementing projects on the ground. This correlates with the many different REDD+ readiness activities and pilot projects in areas of climate change, deforestation and SFM. Only one respondent (of a national CSO) mentioned that CSOs had been conducting FPIC (Free Prior Informed Consent) activities. FPIC is the principle that a community has the right to give or withhold its consent to proposed REDD+ projects that may affect the lands they customarily own, occupy or otherwise use.

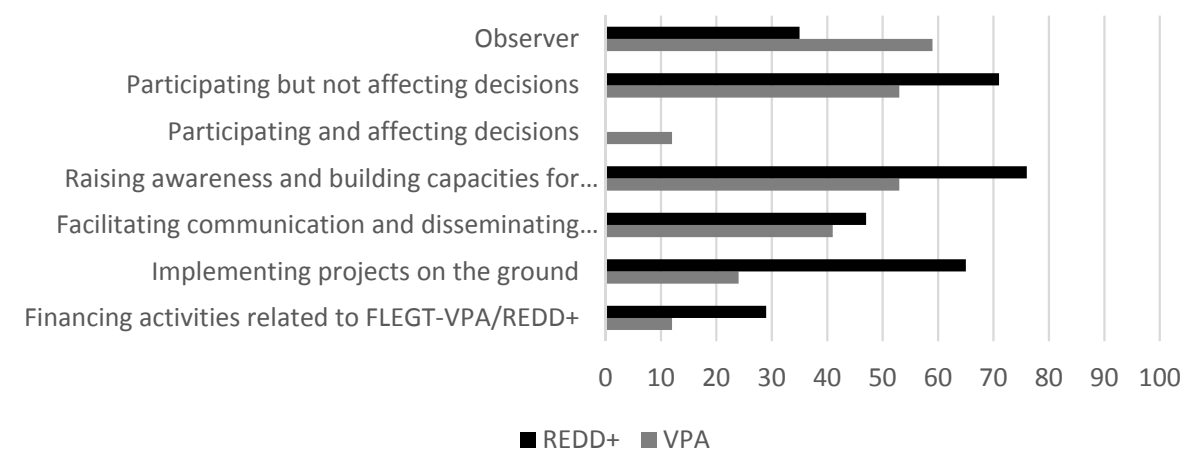

Figure 1. Role of CSOs in REDD+ and FLEGT VPA processes in Lao PDR (number of respondents = 17). 
Figure 1 summarises the types of roles played by CSOs in the FLEGT VPA process in Lao PDR. The category "participating and affecting decisions" had a very low score, with only two respondents indicating this option. Even so, the result was not as drastic as in the case of REDD+ where none of the respondents indicated this option.

Nine respondents thought that the role of CSOs is to raise awareness and help build capacities for others. For instance, a respondent from a national CSO stated that they were providing information to their CSO network, which is an informal network between collaborating actors. Furthermore, as shown in Figure 1, six respondents indicated that "facilitating communication and disseminating information between different levels" was a role of CSOs in the FLEGT VPA process. Later, during face-to-face interviews, a Lao CSO respondent commented that they had been facilitating communication and disseminating information concerning FLEGT-VPA issues for local authorities and local communities and sharing lessons learnt at regional and national level. Lastly, only four of the respondents, in comparison to 11 in the case of REDD+, mentioned that CSOs were "implementing projects on the ground". The difference could partly be explained by the fact that the FLEGT VPA process was still at a very early stage, and CSOs are currently not officially involved in forest law enforcement activities. In reality, however, via their networks, social media and newspapers, they have an important role in monitoring and reporting for example illegal logging activities in Lao PDR, as commented on by an international CSO representative during pre-study interviews.

Much of the wood in Lao PDR originates from conversions of forests to other land uses, such as teak and rubber plantations, hydropower plants and mining and other infrastructure projects. The government of Laos (GoL) has been experimenting with bans on logging and/or log exports from as early as $1991[26,49,62]$ when the nationwide moratorium on all logging concessions was adopted (Decree No. 67, from August 1991). However, logging—legal and illegal—has continued ever since; in the 1980s and 1990s logging was undertaken exclusively by the Lao Army and state owned enterprises, and later by international investments under the pretext of nation-wide development projects.

Several scholars have shown that private investors have so far successfully circumvented the logging ban by using the willingness of the government to grant land concessions for development projects, such as hydropower installations, plantations and mining (see for example [26,49,54]). Regrettably, as scholars and practitioners have by now concluded, many of these development projects never take place because many private investors abuse the development concessions by selling their development concessions to a third party after having logged the land and profited from timber sales. Therefore, large-scale logging has continued to a greater or lesser extent in Lao PDR despite the formal logging moratorium.

Separate questions were posed about challenges related to the participation of CSOs in REDD+ and in FLEGT VPA processes, but the data show noticeable similarities between both cases. Therefore, these results are presented jointly. Based on the responses, four main categories of challenges were identified: (i) governmental control and lack of an enabling political environment for CSOs to operate; (ii) limited understanding about REDD+ and FLEGT-VPA processes and their complexity; (iii) limited human and financial resources within the CSOs; and (iv) few national efforts in enabling REDD+ and VPA implementation in the country.

The first and main challenge raised during the survey, but also during face-to-face interviews among the respondents, is that the political system does not support or facilitate the operation of an independent civil society. Respondents also expressed a perception that the government exercises strict central control over REDD+ and related issues, as well as over the FLEGT-VPA process. One of the national key informants argued during pre-study face-to-face interviews in 2014 that it is generally difficult for non-state actors, including CSOs, to influence or affect government policy processes. These views are in line with the country's political reality, which limits the functioning of a free and independent civil society. During the survey, another national CSO respondent claimed that there is no free speech and that it will never be possible in the current political context. Moreover, 
the government is intending to pass new decrees that would restrict the operation of international CSOs as well as the establishment and registration of national CSOs in the country [48]. Consequently, media with a focus on the region, such as South China Morning Post (17 September 2014) and Radio Free Asia (2 October 2014), have been worried that this would curb the space for open dialogue in Lao PDR society. The new decrees would further strengthen government control over CSOs in Lao PDR, and possibly impede the funding of CSOs with foreign money.

More specifically for REDD+ and FLEGT VPA processes, during the survey, a government representative explained that there is a lack of an enabling regulatory and institutional framework for CSO participation. Progress in national REDD+ development has remained fairly limited, and this is reflected in the survey responses. REDD+ as well as FLEGT require an institutional setup that promotes and facilitates multiactor participation in order to have all relevant actors involved in the process. Additionally, a survey respondent of a foreign government agency argued that a CSO representative should be a member of the national REDD+ Task Force and participate in the decision making process on REDD+. The same respondent also noted that such a development is not likely to happen in the near future. Moreover, for the FLECT VPA process, a survey respondent of an international NGO explained that not many CSOs work on this because the topic of FLEGT VPA is a sensitive issue in Laos. The respondent further explained that forest law enforcement and monitoring of illegal logging will be difficult to implement at a local level because such actions would run counter to national and subnational income from the unlicensed logging activities. Indeed, based on several documents and articles, illegal logging and related trade are controversial issues in the country because it is argued that influential actors from the private and the public sector are involved in these trades and powerful vested interests exist $[26,49,70]$.

The second and equally important fundamental challenge concerns the technical complexity of REDD+ and lack of knowledge and understanding about FLEGT VP. This challenge holds true for most of the actors involved in both processes. While it is important for participating actors to understand the processes and how the processes relate to each other and other factors (such as forest monitoring, forest management planning, logging licencing), there has been little information dissemination and capacity building to address the issue. Ambiguity about REDD+ will drive actors' interests down and it will be difficult for the process to gain momentum. One respondent of an international NGO stated that it is difficult to see how REDD+ relates to the communities, i.e., to their participation and benefits. In addition, on several occasions, the lack of REDD+ structures, pilot project structures and progress were pointed out as obstacles and barriers for REDD+ implementation. This implies that four years after the approval of the country's R-PP's, there is still a need for extensive capacity building among actors "outside of the country's capital". As one respondent of an international organisation put it, there is need to simplify REDD+ and make it understandable for a wider range of actors. Arguably, this is challenging when overall progress with REDD+ in Lao PDR has been slow, and institutional and regulatory developments within the process have been lagging behind. The same logic applies to the VPA process; without sufficient understanding, actors cannot properly engage in the VPA process. Moreover, awareness of the VPA process among Lao CSOs and communities is still low, as pointed out by some respondents from private sector and community-based organisations. A key informant also stated that awareness of VPA is even lower than that of REDD+.

The third significant challenge is a lack of capacities. The Lao NPAs were specifically pointed out as lacking human, financial and project management capacities in relation to REDD+ and VPA processes. According to a key informant's interviews, the most pressing issues are the lack of financial and properly trained human resources in the NPAs. A respondent of a foreign government agency also stated that NPAs do not have adequate knowledge about international policy processes, and the "big picture" surrounding those processes. Lack of these capacities and resources undoubtedly has to do with the very recent emergence of Lao civil society organisations and the limited political space for their activities and growth. This issue will need to be addressed for Lao NPAs to be able to effectively engage in REDD+ and VPA processes. However, in the current setting, this is only 
possible with facilitation by the national government. This is because the government, by passing laws and regulations, ultimately determines the degree to which NPAs may or may not be allowed to develop themselves.

The fourth challenge reflects the government's perceived lack of national efforts in enabling REDD+ and VPA implementation in the country. One respondent from the national level said that there is a contradiction in the national vision of development. The issues of conservation and of contradictory government policies were again mentioned by another respondent and an informant in 2016, as also evidenced by [71]. Further, a respondent of an international NGO stated that there is a lack of initiative with regard to the REDD+ process within the government. Instead of national authorities or national CBOs, the key players have been the bilateral and multilateral donor projects (such as CliPAD, and JICA's F-REDD project). The CSOs and the INGOs do not have a clear role in the REDD+ process in Lao PDR. SNV (an INGO founded in the Netherlands in 1965, with local presence in many countries in Asia, Africa and Latin America) has been active through their REDD+ pilot project, but this support was available only until October 2016.

A key informant explained that the green light from the government to involve CSOs in the FLEGT-VPA process has been pending. Understandably, it can become difficult to involve CSOs in the REDD+ or VPA process if the process lacks clear structure, direction and momentum [72], and the government is first and foremost responsible for all of these. For instance, in 2012, in the case of REDD+, the division of DoF between two ministries as a result of institutional reform was seen to cause weaknesses in its capacities; the lack of clarity in institutional mandates thus caused delays in the processing of FCPF grant financing by the World Bank [73]. However, in 2016, structural changes and integration of international experts under DoF were again taking place. This is the result of transfer of the DFRM from the Ministry of Natural Resources and Environment back to the Ministry of Agriculture and Forestry, and the REDD+ office is now being consolidated under DoF.

\subsection{The "Rules of the Game" and Challenges of Realising Cooperation between REDD+ and FLEGT VPA Processes}

Most respondents, in answering the question of future potential cooperation between REDD+ and FLEGT-VPA process, identified various opportunities such as matters concerning governance of forest, the law reform and enforcement. These three aspects relate to the interlinkages between the rules of the game and resources (the two analytical dimensions included in the PAA; see for example $[63,65])$. The "rules of the game" are closely related to actors' resources and therefore to power during the policy game: Who participates in the policy development related to REDD+ and FLEGT-VPA? Are CSOs excluded or will they participate in the future? If CSOs participate in the policy game, they need resources, which refers to actors' capacities-economic, political, cultural, knowledge and beyond - and also to the extent to which they are able to exert influence over other actors (i.e., actors' power relationships; see for example [63,65]. While different types of power capacities are certainly interwoven with access to resources, two capacities-the political and the knowledge-based power capacities-may be of special interest in the context of potential participation of CSOs in governance of forests, law reform and enforcement. These two capacities-the political and the knowledge-based power capacities-are central to the rules of the game in REDD+ and FLEGT-VPA processes.

For example, six respondents highlighted the overlap in the institutional structures of the two initiatives and in the potential participation of CSOs to foster cooperation. Foreign government agency respondents pointed out that under the process of REDD+ policy development, key actors such as CSOs should be involved so that duplications and contradictions within VPA process can be avoided. Further, the same respondents said that the work of the technical working groups of both processes should be synchronised. Misunderstanding and miscommunication were said to be the wider issues currently and the organisational setup of both MAF and MONRE were described as very complex. Due to the fact that causes of deforestation and forest degradation largely originate from outside the forest sector [74] and that REDD+ (and also VPA) requires effective cross-sectoral coordination and 
CSOs participation, advanced communication mechanisms within and among ministries would play a key role.

Three respondents also acknowledged that there is potential for cooperation between the two processes in terms of addressing causes of deforestation and forest degradation. The two processes were regarded as providing opportunities for strengthened roles and rights of local communities. A foreign government agency respondent argued, for example, that REDD+ and FLEGT-VPA processes should adopt common approaches for empowering local communities to have rights and means to engage in law enforcement around forests, especially in combating poaching and illegal logging, and to receive real incentives for doing so. This view was shared by a key informant, who also noted CSOs' possible role in training local communities for these actions. A government respondent echoed this view. Beyond deforestation and forest degradation, six different respondents pointed to forest governance in general as an important topic for both processes; some areas for cooperation include access to information and greater transparency, and land law reform and enforcement. As one international expert noted: "Both (processes) are strongly linked to governance issues, so there could be scope for using both processes to improve forest governance." The respondent continued, however, that "(this discussion) would have to involve the policy sector in a broad sense-not just the forestry sector, which operates independently of for example land development sectors."

Figure 2 presents potential challenges to creating cooperation between the two processes. The two options clearly chosen most often were "insufficient capacities" (14 respondents) and 'lack of political will/interest' (13 respondents). The lack of capacities appears to be omnipresent and may undermine many efforts. These findings are linked to the concept of resources and refer to actors' capacities-economic, social and political—as well as to the concept of power.

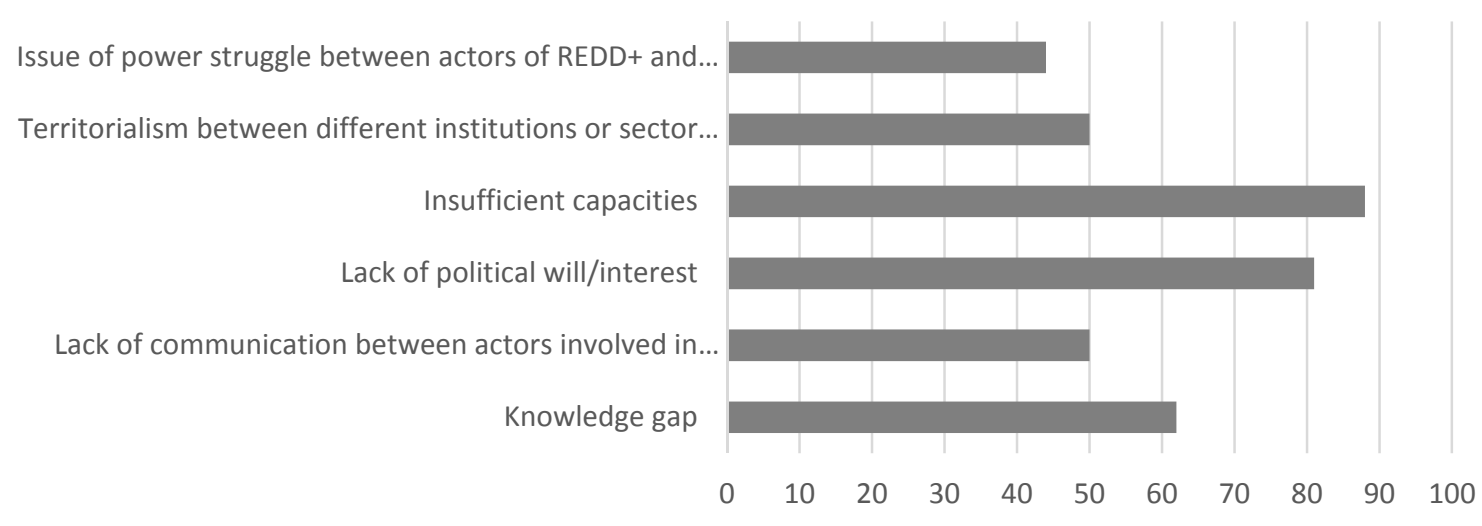

Figure 2. Challenges to cooperation between REDD+ and VPA processes (number of respondents = 16).

For example, the interviewed foreign government agency representative highlighted both processes as requiring significant investments from the Lao government, and that coordinated cooperation between REDD+ and VPA processes could lead to increased efficiency. There could consequently be a reduced need for financial and human resources, therefore such cooperation could be something to truly strive for in the country context of Lao PDR. A foreign government agency respondent explained the lack of political will or interest as related to the fact that (in the case of the VPA process) very little timber from Lao PDR goes to Europe and that benefits from REDD+ are still unclear: "So, what is the incentive for the Lao government to take them seriously?" This lack of interest could partly be explained by the third most chosen option (10 respondents), namely the "knowledge gap" about the processes and possible cooperation between them. Understanding opportunities for cooperation and its potential benefits first requires in-depth knowledge of each process, which is not yet the case for many actors in Lao PDR. An international NGO respondent argued that REDD+ and VPA concepts are new to Lao PDR and capacities of relevant government and private actors in relation to these concepts were still very low. A Lao CSO respondent explained that many people were saying 
that these issues were new for them and very difficult to understand, so they did not become interested in them in the first place. This indicates the need for awareness raising and capacity building.

Respondents also acknowledged that the "issue of power struggle between actors of REDD+ and VPA processes" (7 respondents), "territorialism between different institutions or sector organisations" (8 respondents) and "lack of communication between actors involved in REDD+ and FLEGT-VPA" (8 respondents) also pose challenges to bringing about cooperation between the processes. Each of these difficulties also relates to the same cross-sectoral aspect of different ministries and organisations that are involved in the same governance matters. These issues are not unique to Lao PDR (see e.g., [20] Tegegne et al., 2014 for similar findings in Cameroon and Congo Basin countries); both REDD+ and FLEGT-VPA require improved governance involving multiple actors in order to be successful. Therefore, strong leadership and coordination across sectors and institutions is instrumental to progress.

One of the respondents (a representative of a foreign government agency) explained the current lack of cooperation as being due to several factors. According to another respondent discussions and coordination between the processes cannot be constructive when the institutional setup for REDD+ is still ambiguous and the collaboration among actors generally weak. The respondent further added that the agency in charge had not shown strong leadership in coordination. Moreover, institutional and human capacity is quite limited and actors cannot understand well the requirements of both initiatives, and therefore it is quite difficult to discuss the duplication, demarcation and cooperation of the initiatives among actors.

Finally, respondents were also asked to evaluate at what organisational/administration/interest level(s) they believed that challenges to cooperation would occur (Figure 3). Here, a trend of increased "likelihood" of challenges is observed to occur from lower towards higher levels of governance. The implication is that decision-making power is concentrated at higher levels of governance rather than at lower levels, as in a 'top-down' system. This is because challenges would occur at the level where actual decisions are being made and authority is located. On the other hand, a foreign government agency respondent argued that 'once you have a successful case at village level, district government will become your ambassador to the higher levels of government'. Challenges that prevent or obstruct cooperation would still need to be tackled at all levels, with sufficient attention being paid to central and provincial levels.

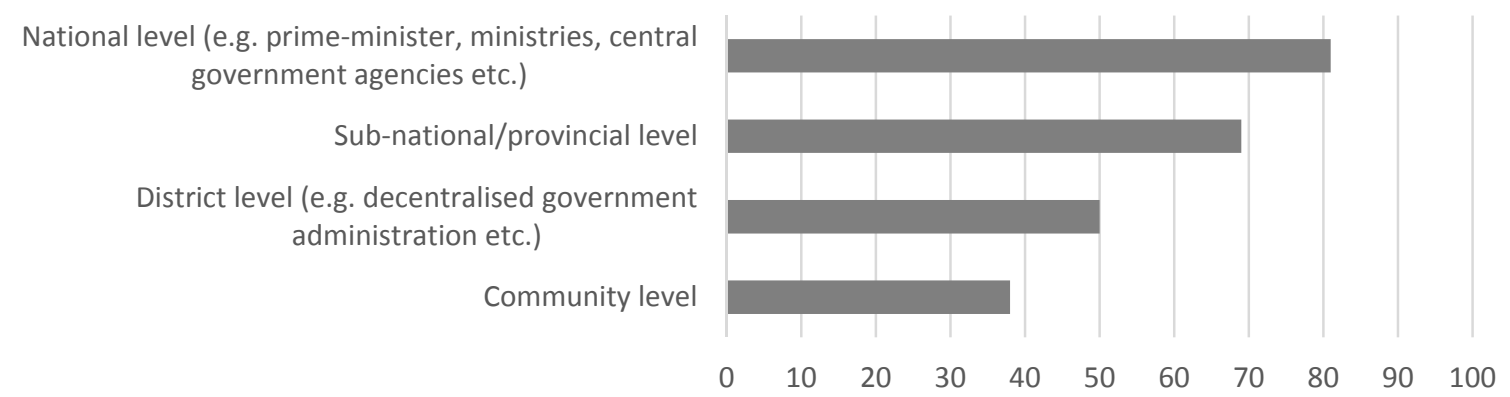

Figure 3. Perceived occurrence of challenges related to cooperation at different levels (number of respondents $=16$ ).

The literature describes how for one process or regime to be able to "learn" from another process and apply the lessons learnt, their institutions and/or membership must overlap $[19,20,75]$. In the REDD+ and FLEGT-VPA processes in Lao PDR, as described in detail in Section 2.3, several albeit shifting and therefore relatively complicated institutional connections and overlaps do exist between actors and institutions involved. Based on interviews as well as national documents (such as [57]), it is possible that more and new overlaps will come into effect as both processes take shape and evolve. Currently, existing overlaps imply that the REDD+ and FLEGT-VPA processes already have interlinks in memberships and thus are able to "learn" from each other and apply lessons learnt. However, 
both of these processes are centrally controlled, and although CSOs could have resources to support the implementation of both processes, currently CSOs have limited access to set the rules of the game, as we further elaborate in Section 6.

\section{Conclusions and Recommendations}

The national CSOs in Lao PDR are composed of the newly emerging Non-Profit Associations (NPAs). However, the government does not view these organisations as independent players nor as a balancing force or counterweight to government policies, as is the case in many other countries [46]. In other words, the government does not share power with these actors (nor any other) but retains central control and power for itself $[46,76]$. Instead, the government recognises that CSOs should play a role in advancing development in the country, but this role should not contradict government policies and goals [48]. The political environment in Lao PDR provides the frame for the conceptual understanding of resources, which refers to the extent to which CSOs are able to exert influence over central control and power (actors' power relationships, as referred to in Bas Arts' conceptual frame [69]). Based on this interpretation, the rules of the game in REDD+ and FLEGT-VPA processes can be understood through the following crucial questions $[63,65]$ : Who decides on the policy agenda and processes? Who may participate? Who decides the implementation?

The results of this study suggest that participation of international and local CSOs in REDD+ and FLEGT-VPA processes in Lao PDR is limited and significantly constrained. Where the CSOs are able to participate, the nature of that participation seems not to actually affect decisions that steer the processes, but serves merely to raise awareness and to a lesser degree to bring about implementation of local pilot project activities. Moreover, for the most part, the same kinds of challenges exist and hinder meaningful participation of local CSOs in both REDD+ and FLEGT-VPA; i.e., awareness and knowledge of the processes are low, and local CSOs lack capacities to a significant extent. The political system and governance structures of Lao PDR are also unsupportive of open and free participation by local as well as international CSOs. The respondents felt that local CSOs need better knowledge of REDD+ as well as of FLEGT-VPA and that experiences from other countries could be utilised to link these processes together and provide meaningful ways for CSOs to participate in them. While evidence of existing forms of cooperation between REDD+ as well as of FLEGT-VPA was limited, respondents identified a potential for bringing about cooperation in the future. For this to happen, the respondents again stressed the importance of building the capacities of all the actors involved. Three respondents also acknowledged that there is potential for cooperation between the two processes/international regimes in terms of addressing causes of deforestation and forest degradation (c.f., similar experiences related to the two international regimes in Cameroon and the Republic of Congo [20]).

Interaction of international regimes is premised on the fact that these regimes influence the development and performance of each other in several ways [77]. The interactions between policies depend on the overall political and institutional setting in which policies or regimes exist and interact [78]. This paper contributes to the literature on these interactions by investigating rules of the game and how CSOs could strengthen the interactions between FLEGT and REDD+ in Lao PDF country context.

Country context is important when it comes to effectiveness and pace of REDD+ readiness [79] or other natural resources governance-related processes. Indeed, the seemingly slow progress of Lao PDR in REDD+ and FLEGT-VPA can be partly explained by overall weak governance, the current political environment, and lack of resources. Thus, we see the multifaceted nature of power in relation to availability of resources and the capacity to achieve outcomes [69]. Participation and cooperation can be presupposed to require that specific actors exercise power if they are to perform these functions. But weak capacity or willingness of the government institutions and/or other "duty bearer" agencies will hinder the formulation of the rules etc. needed to make participation/cooperation happen. For example, in Lao PDR, the issue of weak forest governance is partly seen as a result of lack of a regulatory framework and legislation. However, while some inconsistencies and loopholes do 
exist, the enforcement and implementation in particular of laws and policies in Lao PDR is also acknowledged to be poor $[32,49,57]$.

The latest in over two decades of GoL logging and/or log export bans is the new Prime Minister's Order (PM's Order 15) ban on timber exports, issued in May 2016. The moratorium does not exempt project developers or infrastructure-concession operators, and requires them not to use timber to pay for infrastructure development projects. In addition, the government is in charge of logging and selling wood directly to project developers and concession operators. In December 2016, the Laotian Times reported that the PM's Order 15 had successfully curbed harmful practices in the forestry sector and timber industry. The scientific community has therefore been led to believe the implementation of the Order has so far been taken seriously. There have as yet been no formal studies to support the merits of this Order and immediate and urgent research into these claims is required.

Thompson, Baruah and Carr [16] point out that it is problematic that states are typically treated as the main parties responsible for implementing REDD+, when they do not have sufficient capacities to successfully enforce rules and regulations. The kind of outcomes that are actually achieved depend, however, on the types of resources actors possess and how they use them, and on how actors play the whole "policy game", i.e., are influenced by which rules. Rules of the game decide the (non)existence of cooperation, who may participate and who decides this. Those who make the decisions and achieve outcomes are the actors with the greatest resources (e.g., political and knowledge-based power). A recent study [79] across REDD+ countries also found that not much attention is paid to subnational-level processes. As the REDD+ and FLEGT-VPA processes in Lao PDR evolve, state actors will need to consider how CSOs can be better involved in the processes, and in what roles, so as to utilise their capacities and for the CSOs themselves to benefit from the processes.

Currently, in Lao PDR, international and national CSOs are to a great extent concerned about and affected by their opportunities to participate in natural resources governance. In this situation, where local communities are adjusting to REDD+ and FLEGT-VPA to be able to benefit from global flows of values, CSOs are being placed in an increasingly important role, serving as the voice of the community. Traditionally, CSOs have been the weakest actors in natural resources governance in Lao PDR, but CSOs now perceive their role to be growing stronger. In the case of REDD+ and FLEGT-VPA, CSOs (both national and international) are acting as the mediators between global contexts and local conditions.

In Lao PDR, international and national CSOs should and do have a role in facilitating both REDD+ and FLEGT-VPA processes. However, it is important to remember this basic rule of the game in life in general: the actors with the greatest resources can easily overrule the decision making of those with fewer resources. There is also therefore a risk that externally funded and hence greater resourced CSOs "speak on behalf" of local communities and that local governance structures are bypassed in the process. There is further research needed on how the district and provincial level governance and village organisations, such as mass organisations (e.g., youth and women's unions) and forest management units at village level, will be integrated in the REDD+ and FLEGT-VPA processes, because they are key actors in the reduction of deforestation and forest degradation and enforcement of forest law.

This study has important implications for the countries in the Southeast Asian region involved in the FLEGT VPA and REDD+ processes, and in particular those such as Vietnam and Cambodia with similar socio-political environments. The finding that CSOs have a key role to play in strengthening cooperation and interactions between REDD+ and FELGT VPA, as well as in awareness raising and pilot project implementation, make it imperative to address further the participation challenges faced by CSOs in the region.

Limited understanding of REDD+ and FELGT VPA processes and limited human resources were identified as key challenges to CSO participation. On the other hand, according to the study, CSO understanding and resources are likely to improve in step with stronger CSOs which have a key role in raising awareness about FLEGT and REDD+. In other words, creating and promoting 
enabling conditions for a better involvement of CSOs is an important strategy to address barriers to CSO participation. In Lao PDR, the authoritarian regime would surely benefit from a more open and inclusive approach. Such an approach would in turn increase the legitimacy of government operations as well as acceptance of external interventions, such as FLEGT VPA and REDD+ processes. Social resistance-either hidden or more strategic and organised-continues to obstruct both acceptance of state authority and implementation of international interventions in Southeast Asia [80]. We therefore argue in favour of participation of non-state actors as a strategy for smoother implementation of environmental governance interventions in general and of FLEGT and REDD+ in particular.

Acknowledgments: We would like to acknowledge all respondents in Lao PDR who took part in the study survey. This work was part of a long-term study funded by the Academy of Finland (grant number 265,159) called "REDD+: The new regime to enhance or reduce equity in global environmental governance? A comparative study in Tanzania, Mexico and Laos". The authors closely cooperated within this comparative research project. We would especially like to acknowledge Salla Rantala and Paula Williams for all their valuable comments, and a warm thanks is extended to Yidnekachew Biza for his research assistance. The European Forest Institute is also acknowledged for institutional support. We also acknowledge the proofreading support of Nick Quist Nathaniels.

Author Contributions: Irmeli Mustalahti, main author; Mathias Cramm, collecting and analyzing data; Sabaheta Ramciloviv-Suominen, REDD+ issues and literature analysis; Yitagesu T. Tegegne, FLEGT VPA issues.

Conflicts of Interest: The authors declare no conflict of interest.

\section{References}

1. Intergovernmental Panel on Climate Change (IPCC). Summary for Policymakers. In Climate Change 2013: The Physical Science Basis; Contribution of Working Group I to the Fifth Assessment Report of the Intergovernmental Panel on Climate Change; Stocker, T.F., Qin, D., Plattner, G.-K., Tignor, M., Allen, S.K., Boschung, J., Nails, A., Xia, Y., Bex, V., Midgley, P.M., Eds.; Cambridge University Press: Cambridge, UK; New York, NY, USA, 2013.

2. Achard, F.; Beuchle, R.; Mayaux, P.; Stibig, H.J.; Bodart, C.; Brink, A.; Carboni, S.; Desclee, B.; Donnay, F.; Eva, H.D.; et al. Proximate causes and underlng driving forces of tropical deforestation. Glob. Chang. Biol. 2014, 20, 2540-2554. [PubMed]

3. Hansen, M.C.; Potapov, P.V.; Moore, R.; Hancher, M.; Turubanova, S.A.; Tyukavina, A.; Thau, D.; Stehman, S.V.; Goetz, S.J.; Loveland, T.R.; et al. High-resolution global maps of 21st-century forest cover change. Science 2013, 342, 850-853. [CrossRef] [PubMed]

4. Lima, M.G.B.; Braña-Varela, J.; Kleymann, H.; Carter, S. Contribution of Forests and Land Use to Closing the Gigatonne Emissions Gap by 2020; WWF-WUR policy brief; Wageningen University and Research: Wageningen, The Netherland, 2015.

5. United Nations Framework Convention on Climate Change (UNFCCC). Key decisions relevant for reducing emissions from deforestation and forest degradation in developing countries (REDD+). Available online: http:/ / unfccc.int/6917.php (accessed on 15 December 2016).

6. Conca, K.; Dabelko, G.D. Green Planet Blues: Critical Perspectives on Global Environmental Politics; Conca, K., Dabelko, G.D., Eds.; Westview Press: Boulder, CO, USA, 2014.

7. Ebeling, J.; Yasue, M. Generating carbon finance through avoided deforestation and its potential to create climatic, conservation and human development benefits. Philos. Trans. R. Soc. B Biol. Sci. 2008, 363, 1917-1924. [CrossRef]

8. Grieg-Gran, M.; Porras, I.; Wunder, S. How can market mechanisms for forest environmental services help the poor? Preliminary lessons from Latin America. World Dev. 2005, 33, 1511-1527. [CrossRef]

9. Gupta, A. Transparency in Global Environmental Governance: A Coming of Age? Glob. Environ. Politics 2010, 10, 1-9. [CrossRef]

10. The United Nations Framework Convention on Climate Change (UNFCCC). Adoption of the Paris Agreement. Available online: https://unfccc.int/resource/docs/2015/cop21/eng/109r01.pdf (accessed on 15 December 2016). 
11. European Commission. Communication from the Commission to the Council and European Parliament: Forest Law Enforcement, Governance and Trade (FLEGT) Proposal for an EU Action Plan. Available online: http://eur-lex.europa.eu/legal-content/EN/TXT/?uri=CELEX\%3A52003DC0251 (accessed on 15 December 2016).

12. United Nations. Non-Legally Binding Authoritative Statement of Principles for a Global Consensus on the Management, Conservation and Sustainable Development of All Types of Forests. A/CONF.151/26 (Vol. III). Annex III. Available online: http:/ / www.un.org/documents/ga/conf151/aconf15126-3annex3.htm (accessed on 15 December 2016).

13. Ramcilovic-Suominen, S.; Gritten, D.; Saastamoinen, D. Concept of livelihood in the FLEGT voluntary partnership agreement and the expected impacts on the livelihood of forest communities in Ghana. Int. For. Rev. 2010, 12, 361-369. [CrossRef]

14. Rica, C.; Corbera, E.; Estrada, M.; May, P.; Navarro, G.; Pacheco, P. Rights to Land, Forests and Carbon in REDD+: Insights from Mexico, Brazil and Costa Rica. Forests 2011, 2, 301-342.

15. Mustalahti, I.; Bolin, A.; Paavola, J.; Boyd, E. REDD+ reconcile local priorities and needs with global mitigation benefits? Lessons from Angai Forest, Tanzania. Ecol. Soc. 2012, 17, 16. [CrossRef]

16. Thompson, M.C.; Baruah, M.; Carr, E.R. Seeing REDD+ as a project of environmental governance. Environ. Sci. Policy 2011, 14, 100-110. [CrossRef]

17. Beeko, C.; Arts, B. The EU-Ghana VPA: A comprehensive policy analysis of its design. Int. For. Rev. 2010, 12, 221-230. [CrossRef]

18. Dooley, K.; Ozinga, S. Building on Forest Governance Reforms through FLEGT: The Best Way of Controlling Forests' Contribution to Climate Change? Rev. Eur. Community Int. Environ. Law R 2011, 20, 163-170. [CrossRef]

19. Ochieng, R.M.; Visseren-hamakers, I.J.; Nketiah, K.S. Interaction between the FLEGT-VPA and REDD+ in Ghana: Recommendations for interaction management. For. Policy Econ. 2013, 32, 32-39. [CrossRef]

20. Tegegne, Y.; Ochieng, R.; Visseren-Hamakers, I.; Lindner, M.; Fobissie, K. Comparative analysis of the interactions between the FLEGT and REDD+ regimes in Cameroon and the Republic of Congo. Int. For. Rev. 2014, 6, 602-614. [CrossRef]

21. Mustalahti, I.; Taku, T. Forest management in REDD+: New opportunity or more risks? Scand. J. For. Res. 2012, 27, 200-209. [CrossRef]

22. Mustalahti, I.; Rakotonarivo, S. REDD+ and Empowered Deliberative Democracy: Learning from Tanzania. World Dev. 2014, 59, 199-211. [CrossRef]

23. Ministry of Planning and Investment; World Bank. Lao People's Democratic Republic_Investment and Access to Land and Natural Resources: Challenges in Promoting Sustainable Development, a Think Piece (A Basis for Dialogue); World Bank: Washington, DC, USA, 2011.

24. Baird, I.G. Turning Land into Capital, Turning People into Labor: Primitive Accumulation and the Arrival of Large-Scale Economic Land Concessions in the Lao People's Democratic Republic. New Propos. J. Marx. Interdiscip. Inq. 2011, 5, 10-26.

25. Wong, G.Y.; Darachanthara, S.; Soukkhamthat, T. Economic Valuation of Land Uses in Oudomxay Province, Lao PDR: Can REDD+ be Effective in Maintaining Forests? Land 2014, 3, 1059-1074. [CrossRef]

26. Lestrelin, G.; Trockenbrodt, M.; Phanvilay, K.; Thongmanivong, S.; Vongvisoul, T.; Pham, T.T.; Castella, J.C. The Context of REDD+ in the Lao People's Democratic Republic Drivers, Agents and Institutions; Center for International Forestry Research (CIFOR): Bogor, Indonesia, 2013.

27. Mission Aviation Fellowship. Annual Review of REDD+ Activities in Lao PDR 2012-2013; Mission Aviation Fellowship: Vientiane, Laos, 2013.

28. Barney, K. China and the Production of Forestlands in Lao PDR: A political ecology of transnational enclosure. In Taking Southeast Asia to Market: Commodities, Nature, and People in the Neoliberal Age; Cornell University Press: Ithaca, NY, USA, 2008; pp. 91-107.

29. Lestrelin, G. Land degradation in the Lao PDR: Discourses and policy. Land Use Policy 2010, 27, 424-439. [CrossRef]

30. Vongvisouk, T.; Mertz, O.; Thongmanivong, S.; Heinimann, A.; Phanvilay, K. Shifting cultivation stability and change: Contrasting pathways of land use and livelihood change in Laos. Appl. Geogr. 2014, 46, 1-10. [CrossRef]

31. Daoroung, P. Community forests in Lao PDR: The new era of participation? Watershed 1997, 3, 1-8. 
32. Fujita, Y.; Phengsopha, K. The Gap between Policy and Practice in Lao PDR. In Lessons from Forest Decentralization: Money, Justice and the Quest for Good Governance in Asia-Pacific; Colfer, C.J.P., Dahal, G.R., Capistrano, D., Eds.; Earthscan: London, UK, 2008; pp. 117-131.

33. Program, L.F.; Makarabhirom, P.; Raintree, J.; Lao, T.; Forestry, S. Comparison of Village Forestry Planning Models Used in Laos; Pearmsak Makarabhirom and John Raintree Regional Community Forestry Training Center (RECOFTC): Bangkok, Thailand, 1999.

34. Government of Lao PDR. The Forestry Law; Government of Lao PDR: Vientiane, Laos, 1996.

35. Samountry, X.; Bounphasaisol, T.; Leuangkhamma, T.; Phiathep, O.; Wayakone, S.; Williams, P. Evaluation of Forest Management and Conservation Programme. FOMACOP Village Forestry Pilot Model (1995-2000). Technical Report; FOMACOP: Vientiane, Laos, 2001.

36. Mustalahti, I. Participatory forestry in the crossroads in Laos and Vietnam. Two participatory forestry case studies. In Contextualising Natural Resource Management in the South; Vihemäki, H., Ed.; Institute of Development Studies, University of Helsinki: Helsinki, Finland, 2007; pp. 193-236.

37. Government of Lao PDR. Decree on Endorsement and Declaration of the Forestry Strategy to the Year 2020 of the Lao PDR; Government of Lao PDR: Vientiane, Laos, 2005.

38. Mustalahti, I.; Lund, J.F. Where and How Can Participatory Forest Management Succeed? Learning From Tanzania, Mozambique, and Laos. Soc. Nat. Resour. Int. J. 2009, 23, 31-44. [CrossRef]

39. Phanthanousy, B.; Sayakoummane, S. The Lao PDR-Community Forestry in Production Forest 2005; Community Forestry Policy Forum, RECOFTC: Bangkok, Thailand, 2005.

40. Ministry of Agriculture and Forestry. SUFORD Scaling Up. Available online: http://www.suford.org/wpcontent/uploads/2015/01/sufor_scaling_up_brochure.pdf (accessed on 15 December 2016).

41. World Bank. Project Appraisal Document. Scaling-up Participatory Sustainable Forest Management Project; Report No: 75632-LA; World Bank: Washington, DC, USA, 2013.

42. Government of Lao PDR. National Growth and Poverty Eradication Strategy; Government of Lao PDR: Vientiane, Lao People's Democratic Republic, 2004.

43. Government of Lao PDR. Decree on Sustainable Management of Production Forest Areas; Government of Lao PDR: Vientiane, Lao People's Democratic Republic, 2002.

44. Government of Lao PDR. Decree on Associations, No. 115/PM.; Government of Lao PDR: Vientiane, Lao People's Democratic Republic, 2009.

45. Stuart-Fox, M. The Political Culture of Corruption in Lao PDR. Asian Stud. Rev. 2006, 30, 59-75. [CrossRef]

46. Belloni, R. Development in Practice Building civil society in Lao PDR: The Decree on Associations. Dev. Pract. 2014, 24, 353-365. [CrossRef]

47. KEPA. Reflections on Lao Civil Society. Available online: www.kepa.fi/tiedostot/lao_cs_2013.pdf (accessed on 10 November 2014).

48. Government of Lao PDR. Draft Decree on Associations and Foundations; Government of Lao PDR: Vientiane, Lao People's Democratic Republic, 2014.

49. Barney, K.; Canby, K. Baseline Study 2, Lao PDR: Overview of Forest Governance, Markets and Trade; EU FLEGT Facility: Kuala Lumpur, Malaysia, 2011.

50. LIWG. INGOs Important Contributors to Development. Land issues working group: Vientiane, Laos PDR. Available online: http:/ /www.laolandissues.org/2014/10/29/ingos-important-contributors-todevelopment/ (accessed on 15 December 2016).

51. Morning Post. Laos NGO Restrictions Threaten Development, Say Non-Profit Groups. Available online: http:/ /www.scmp.com/news/asia/article/1594490/laos-ngo-restrictions-threaten-developmentsay-non-profit-groups (accessed 15 December 2016).

52. Ministry of Natural Resources and Environment. MoNRE Regarding the Organization and Activities of the Department of Forest Resource Management; Decision No. 3121; Ministry of Natural Resources and Environment: Vientiane, Lao People's Democratic Republic, 2012.

53. Barney, B.K. Power, Progress and Impoverishment: Plantations, Hydropower, Ecological Change and Community Transformation in Hinboun District, Lao PDR. Available online: http://www.cifor.org/ publications/pdf_files/books/bbarney0701.pdf (accessed on 15 December 2016).

54. Baird, I. Quotas, Powers, Patronage and Illegal Rentseeking: The Political Economy of Logging and the Timber Trade in Southern Laos; Forest Trends: Vientiane, Lao People's Democratic Republic, 2009. 
55. Kenney-Lazar, M. Land Concession, Land Tenure, and Livelihood Change: Plantation Development in Attapeu Provinc, Southern Laos. Available online: http:/ /www.laolandissues.org/wp-content/uploads / 2012/01/Kenney-Lazar-Land-Concessions-Attapeu.pdf (accessed on 15 December 2016).

56. Vongvisouk, T.; Lestrelin, G.; Castella, J.; Mertz, O.; Broegaard, R.B.; Thongmanivong, S. REDD+ on hold: Lessons from an emerging institutional setup in Laos. Asia Pac. Viewp. 2016, 57, 393-405. [CrossRef]

57. Readiness Preparation Proposal; Lao PDR. Readiness Preparation Proposal (R-PP). Available online: https:/ /www.forestcarbonpartnership.org/sites/forestcarbonpartnership.org/files/Documents/ PDF/Sep2011/LaoR-PPFinaldraftrevised21DEC2010-CLEAN.pdf (accessed on 15 October 2014).

58. Forest Carbon Asia. New National REDD+ Task Force Appointed in Laos. Available online: http://www.forestcarbonasia.org/in-the-media/new-national-redd-task-force-appointed-laos (accessed on 15 October 2014).

59. Ministry of Natural Resources and Environment. MoNRE on REDD+ Task Force for Implementation of Reducing Emission from Deforestation and Forest Degradation; MoNRE Agreement No. 7176/2013; Ministry of Natural Resources and Environment: Vientiane, Lao People's Democratic Republic, 2013.

60. FERN. Forest Watch FLEGT Update November 2013. Available online: http://www.fern.org/sites/fern. org/files/FLEGT\%20update_0.pdf (accessed on 2 November 2014).

61. EU FLEGT Facility. Stakeholders in Lao PDR Plan Ways to Engage in VPA Processes. Available online: http:/ / www.euflegt.efi.int/laos-news/-/asset_publisher/FWJBfN3Zu1f6/content/stakeholdersin-lao-pdr-plan-ways-to-engage-in-vpa-processes (accessed on 1 May 2016).

62. Saunders, J. Illegal Logging and Related Trade: The Response in Lao PDR; Chatham House: London, UK, 2014.

63. Arts, B.; Leroy, P.; van Tatenhove, J. Political modernisation and policy arrangements: A framework for understanding environmental policy change. Public Organ. Rev. 2006, 6, 93-106. [CrossRef]

64. Arts, B.; van Tatenhove, J. Political modernisation. In Institutional Dynamics in Environmental Governance; Leroy, P., Arts, B., Eds.; Springer: Dordrecht, The Netherlands, 2006; pp. 21-43.

65. Arts, B.; Tatenhove, J. Van Policy and power: A conceptual framework between the "old" and "new" policy idioms. Policy Sci. 2004, 37, 339-356. [CrossRef]

66. Arts, B. "Green alliances" of business and NGOs. New styles of self-regulation or "dead-end roads"? Corp. Soc. Responsib. Environ. Manag. 2002, 9, 26-36. [CrossRef]

67. Arts, B. Assessing forest governance from a "Triple G" perspective: Government, governance, governmentality. For. Policy Econ. 2014, 49, 17-22. [CrossRef]

68. Forsyth, T. Multilevel, Multiactor Governance in REDD+: Participation, integration and coordination. In Realising REDD+: National Strategy and Policy Options; Angelsen, A., Ed.; CIFOR: Bogor, Indonesia, 2009; pp. 113-122.

69. Arts, B. Non-State Actors in Global Governance. Three Faces of Power. Available online: http://hdl.handle. net/11858/00-001M-0000-0028-6C87-B (accessed on 15 December 2016).

70. Vientiane Times. Logging, Tax Avoidance Top 2013 Corrupt Activities in Laos. Available online: https:/ /www.travel-impact-newswire.com/2014/03/logging-tax-avoidance-top-2013-corruptactivities-in-laos/ (accessed on 21 October 2014).

71. Hanssen, C. Lao land concessions, development for the people? Available online: http://www.condesan. org/mtnforum/sites/default/files/publication/files/4948.pdf (accessed on 15 December 2016).

72. Thongmanivong, S.; Phanvilay, K.; Vongvisouk, T. How Laos Is Moving Forward With REDD+ Schemes. Available online: http:/ /epress-dev.lib.uts.edu.au/journals/index.php/ijrlp/article/view/3355 (accessed on 15 December 2016).

73. FCPF. REDD Readiness Progress Fact Sheet, June 2012. Available online: https://www.forestcar bonpartnership.org/sites/forestcarbonpartnership.org/files/Documents/PDF/June2012/Lao PDR REDD Readiness Progress Sheet_June 2012.pdf (accessed on 20 October 2014).

74. Geist, H.J.; Lambin, E.F. Proximate causes and undelying driving forces of tropical deforestation. Bioscience 2002, 52, 143-150. [CrossRef]

75. Gehring, T.; Oberthür, S. The Causal Mechanisms of Interaction between International Institutions 1. Eur. J. Int. Relat. 2009, 15, 125-156. [CrossRef]

76. Jersild, A.; Shroff, R. Feasibility of Various Responses and Interventions to Build Capacity of Local Civil Society Organizations (CSOs) in the Lao PDR. Available online: https://www.adb.org/sites/default/files/ publication/28968/csb-lao.pdf (accessed on 15 December 2016). 
77. Van Asselt, H.; Zelli, F. Connect the dots: Managing the fragmentation of global climate governance. Environ. Econ. Policy Stud. 2014, 16, 137-155. [CrossRef]

78. Gupta, A.; Pistorius, T.; Vijge, M.J. Managing fragmentation in global environmental governance: The REDD+ Partnership as bridge organization. Int. Environ. Agreem. Polit. Law Econ. 2016, 16, 355-374.

79. Minang, P.A.; van Noordwijk, M.; Duguma, L.A.; Alemagi, D.; Do, T.H.; Bernard, F.; Agung, P.; Robiglio, V.; Catacutan, D.; Suyanto, S. REDD+ Readiness progress across countries: Time for reconsideration. Clim. Policy 2014, 14, 685-708. [CrossRef]

80. Singh, S. Natural Potency and Political Power: Forests and State Authority in Contemporary Laos; Series of Southeast Asia: Politics, Meaning, and Memory; University of Hawai'i Press: Honolulu, HI, USA, 2012 ; p. 224.

(C) 2017 by the authors. Licensee MDPI, Basel, Switzerland. This article is an open access article distributed under the terms and conditions of the Creative Commons Attribution (CC BY) license (http://creativecommons.org/licenses/by/4.0/). 